\title{
Tissue damage and embryonic malformation induced by aqueous extract of Pteridium aquilinum on chorioallantoic membrane of chick embryo (CAM)
}

\section{Danos teciduais e malformações morfológicas induzidas pelo extrato aquoso de Pteridium aquilinum sobre a membrana corioalantóide (MCA) e o embrião de galinha}

\author{
Amanda Leitolis ${ }^{1}$; Fernanda Gimenez de Souza ${ }^{2}$; Kelli Freitas ${ }^{3}$; Helyn Barddal ${ }^{4}$; \\ Laryssa Rauh ${ }^{5}$; Joceline Franco ${ }^{5}$; Luiz Fernando Pereira ${ }^{5 *}$
}

\begin{abstract}
The aim of this study was evaluate the effects of Bracken fern (BF) (Pteridium aquilinum (L.) Kuhn.) on biological systems. When consumed by animals can cause acute intoxication, hematuria, biochemistry alterations and cancer. To humans the toxicity is associated with its intake on contaminated ground water or milk and inhalation of its spores. In order to check the BF aqueous extract (AEB) deleterious effects on animals blood vessels system, chick embryo chorioallantoic membrane (CAM) was used. It were applying on CAM $0.1,0.5,1,5,10$ e $15 \mu \mathrm{g} / \mathrm{mL}$ of AEB and saline as control. The angiogenesis was analyzed and the vascular density index (VDI) calculated. The CAM samples were prepared and stained with H\&E to evaluation of microvessels, Masson's trichrome to characterize collagen and fibrin deposition and Picro-sirius used to evaluate collagen using polarized light. Also the morphological aspects of embryos were analysed. We observe on the results of neovascularization that AEB did not change significantly the number of vessels $/ \mathrm{mm}^{2}$, however, membranes treated with AEB (5 or $10 \mu \mathrm{g} /$ $\mathrm{mL}$ ) exhibit opacity and tissue fibrosis, both signs of inflammation. Histological analysis with Masson's trichrome and picro-sirius on tissues exposed to AEB respectively has shown increased collagen fibers and presence of fibrilar collagen. The embryos exposed to concentrations of 5 or $10 \mu \mathrm{g} / \mathrm{mL}$ AEB, showed changes as poor face formation and poor closing of abdominal wall. The highest concentration of AEB $(15 \mu \mathrm{g} / \mathrm{mL})$ was lethal to embryos. Although significant effects on the CAM's vasculature has not observed, tissue aggression was detected, a desmoplasia (an extensive inflammatory signal triggered by tissue injury), changes caused on embryos as well as the presence of toxic substances in the AEB show us an important and deleterious pathway of this bracken fern extract on its intoxicants effects on humans and animals, and even cancer or the death of animals.
\end{abstract}

Key words: Bracken Fern. Chick embryo. Chorioallantoic membrane (CAM). Pteridium aquilinum.

\footnotetext{
${ }^{1}$ Discente do Curso de Doutorado, Programa de Pós-Graduação em Biologia Molecular, Universidade Federal do Paraná, UFPR, Curitiba, PR, Brasil. E-mail: aleitolis@gmail.com

${ }^{2}$ M.e em Ciência da Saúde, Pontifícia Universidade Católica do Paraná, PUCPR, Curitiba, PR, Brasil. E-mail: fernanda.gimenez@ outlook.com

${ }^{3}$ M.e em Biociências/Odontologia, PUCPR, Curitiba, PR, Brasil. E-mail: freitaskelli@hotmail.com

${ }^{4}$ Discente do Curso de Doutorado do Programa de Pós-Graduação em Bioquímica, UFPR, Curitiba, PR, Brasil. E-mail: barddalh@ yahoo.com.br

5 Profs., Escola de Ciências da Vida, ECV, PUCPR, Curitiba, PR, Brasil. E-mail: laryssarauh@yahoo.com.br; jocelinefranco@ hotmail.com; luif33@hotmail.com

* Author for correspondence
} 


\section{Resumo}

O foco principal desse estudo foi avaliar os efeitos do extrato aquoso de Samambaia (EAS) (Pteridium aquilinum (L.) Kuhn) sobre sistemas biológicos. A ingestão das folhas de Samambaia pode provocar intoxicação aguda, hematúria, alterações bioquímicas e câncer se consumida por animais. Em humanos também pode provocar intoxicação ao ser ingerida com água ou leite contaminados e pela inalação de seus esporos. Considerando os efeitos danosos provocados pelo consumo dessa planta esse estudo analisou a ação do EAS sobre um sistema de vasos sanguíneos, a membrana corioalantóide (MCA) de embrião de galinha. Sobre a MCA foram aplicados $0,1,0,5,1,5,10$ e $15 \mu \mathrm{g} / \mathrm{mL}$ de EAS, salina como controle. A angiogênese foi analisada e o índice de densidade vascular (IDV) calculado. Amostras da CAM foram coradas com H\&E para avaliação de microvasos, Tricrômico de Masson para caracterização de colágeno e deposição de fibrina e Picro-sirius para analisar o colágeno através de luz polarizada. Os aspectos morfológicos dos embriões também foram analisados. Os resultados da neovascularização mostraram que não houve mudança significativa do número de vasos $/ \mathrm{mm}^{2}$. Entretanto, as membranas tratadas com 5 ou $10 \mu \mathrm{g} / \mathrm{mL}$ EAS exibiram uma opacidade junto com um tecido fibroso, ambos sinais de inflamação. Corroborando, as análises com Tricrômico Masson e Picro Sirius, respectivamente, apontaram para um aumento das fibras colágenas e presença de colágeno fibrilar. Embriões expostos às concentrações de 5 e $10 \mu \mathrm{g} / \mathrm{mL}$ do EAS sofreram malformações na face e na parede tóraco-abdominal. A concentração de $15 \mu \mathrm{g} / \mathrm{mL}$ foi letal para os embriões. Embora efeitos significativos na vasculatura da MCA não tenham ocorrido, observou-se desmoplasia (um grande sinal de inflamação). Esse fato, juntamente com as malformações no embrião e a presença de compostos tóxicos no EAS inferem, se a planta for ingerida, uma via importante para explicar a intoxicação de animais e humanos, e até mesmo o câncer ou a morte de animais.

Palavras-chave: Embrião de galinha. Membrana corioalantóide (MCA). Pteridium aquilinum. Samambaia.

\section{Introduction}

Bracken fern (BF) (Pteridium aquilinum (L.) Kuhn), Dennstaedtiaceae family member, is regarded one of the five most abundant plants on the Earth and is present in all continents, except Antarctica (SMITH, SEAWRIGHT, 1995). Among the important features of this genre, is its opportunistic behavior, which in forests recently felled or burned, allows the large spread of this plant that quickly turns into a weed difficult controllable (ROOS et al., 2010).

In addition to the environmental impact caused on other plant species by the abundance of bracken fern, $\mathrm{BF}$ is one of few higher plants able to causing cancer naturally in animals (MASUDA et al., 2011). Furthermore, lot of intoxications are caused to this plant, they depend on the species involved and the amount consumed. Syndromes in farm animals have been reported: thiamine deficiency, acute bracken intoxication, progressive retinal degeneration, bovine enzootic hematuria and carcinomas in the upper alimentary tract (PANTER et al., 2007; VETTER, 2010).

In humans, BF toxicity is associated with plant intake, direct exposure to contaminated groundwater, milk intake from cows that consumed $\mathrm{BF}$ and inhalation of the plant spores (ALONSOAMELOT, 1997; SHAHIN et al., 1999). Indeed, there are many toxic and carcinogenics compounds presents in BF, nevertheless, the ptaquiloside is regarded its main carcinogenic agent (YAMADA et al., 2007; VIRGILIO et al., 2015).

The choriollantoic membrane of chicken embryo (CAM) is a structure formed between five and six days of embryo development by fusion of membranes chorion and allantoic (RIBATTI, 2016). Histologically comprises three main layers, the ectoderm, the endoderm and the mesoderm, this latter is enriched with blood vessels and stromal components (MELKONIAN et al., 2002; RIBATTI, 2014). CAM is most commonly used for studies of angiogenic effects (HAZEL, 2003; EUN, KOH, 
2004; FREITAS et al., 2013), tissue responses to biomaterials (VALDES et al., 2002; KLUEH et al., 2003) and effects of plants extracts and drugs (MENG et al., 2008; BOLLER et al., 2015; TOMAZELI et al., 2015). Considering BF has several components with toxic effects to animals, the aims of this study were evaluate the biological effects of Pteridium aquilinum aqueous extract in CAM vasculature and morphology of the embryos.

\section{Material and Methods}

Aqueous extract of BF (AEB) preparation

Leafs of Pteridium aquilinum (L.) Khun, Dennstaedtiaceae, were collected in Experimental Farm Gralha Azul of Pontifical Catholic University of Parana (PUCPR), Fazenda Rio Grande, Curitiba Metropolitan Region, Paraná (Brazil) and identified by HUCP Botanic Museum of Pontifical Catholic University of Parana (PUCPR) (Voucher specimen number 15128). After collected, leafs were dried at room temperature and crushed to smaller fragments. For aqueous extract preparation, $20 \mathrm{~g}$ of sample was mixed with $200 \mathrm{~mL}$ of water under magnetic stirring for 72 hours at room temperature and away from light. For applying on CAM, the AEB was prepared in concentrations of $0.1,0.5,1,5,10$ e $15 \mu \mathrm{g} / \mathrm{mL}$ and then, mixed to $0.5 \mathrm{~mL}$ of $1 \%$ saline gel.

\section{CAM assay}

All animal procedures were conducted after approval of the Ethics Committee on Animal Use at the Pontifical Catholic University of Parana (CEUA - PUCPR, No 356). Fertilized chicken eggs (Gallus gallus domesticus) were kindly donated by the DaGranja Ltda. Company (Mariental-PR, Brazil) and incubated at $38^{\circ} \mathrm{C}$ and $55 \%$ relative humidity. On sixtieth $\left(6^{\text {th }}\right)$ day of development (in an automatic incubator), the eggs were cleaned with ethanol $70 \%$ and CAM was exposed by opening a window about $2 \mathrm{~cm}^{2}$ in the egg shell. Then, the implant formed by $0.5 \mathrm{~mL}$ of $1 \%$ saline gel plus
$0.1,0.5,1,5,10$ or $15 \mu \mathrm{g} / \mathrm{mL}$ of AEB (10 embryos per group), were placed on the chorioallantoic membrane, $0.5 \mathrm{~mL}$ of $1 \%$ saline gel alone was used as control. The window was sealed with sterilized plastic tape $\left(3 \mathrm{M}^{\mathrm{TM}}\right)$ and the eggs were returned to the incubator. The implants were completely absorbed after one week. All these procedures were developed with sterile materials and environment. On day 13 of incubation, the windows were reopened, viewed and extended to a diameter of about $3 \mathrm{~cm}^{2}$ and the response to the different concentrations of AEB was photographed and analyzed by gross evaluation and histological analysis.

\section{Gross evaluation of angiogenesis in CAM}

To gross evaluation of angiogenesis in CAM, the macroscopic appearance of CAMs was examined and photographed under Olympus SZ40 stereomicroscope coupled to a digital camera (Sony 7.2 DSC-W7). Angiogenesis was analyzed using Image-Pro Plus software ${ }^{\mathrm{TM}}$ (version 4.5) at this program we calculate the vascular density index (VDI). VDI represents the number of intersections made by blood vessels (arterioles and venules) with a square grid containing nine smaller squares superimposed on the micrographs (YANG et al., 2005). Vessels were counted three times in random quadrants to obtain an average of vessels per $\mathrm{mm}^{2}$ of each photograph. Were used 10 repetitions per each experimental group (n).

\section{Histological evaluation of CAM tissues}

For histological evaluation of CAM tissues, membrane samples were removed, cleaned and fixed in ALFAC (formaldehyde, ethanol 80\%, glacial acetic acid) solution, embedded in paraffin, sectioned, and stained with (i) hematoxylin - eosin (H\&E), to evaluation of microvessels (arterioles and venules) (ii) Masson's trichrome, to characterize collagen and fibrin deposition in CAM tissues and (iii) Picro-sirius, also used to evaluate collagen, but 
using polarized light microscopy. The stained slides were observed and photographed under a light microscope (Olympus BX50).

\section{Embryos morphology evaluation}

After CAM removal, the embryos were quickly removed from eggs and immediately euthanized with an overdose of thiopental (i.m.). Then, the animals were placed in Petri dishes, examined and classified into two groups: (i) Normal pattern, animals presented a pattern of species (size, curvature and training of members), proper closure of the thoracic and abdominal regions and differentiation of facial structures, and (ii) change in the normal pattern development, animals that showed different development described above.

\section{Chemical composition analysis of $A E B$}

For qualitative chemical composition analysis of AEB photochemical exploration was performed to identify the presence or absence of metabolites anthocyanin glycosides, saponin glycosides, cyanogenic glycosides, Amino groups, fixed acids, volatile acids, tannins by colorimetric and precipitation reactions (FRANCO et al., 2005).

\section{Statistical analysis}

The results were described as the mean \pm standard error of the mean (SEM). Statistical analysis was performed using one-way analysis of variance (ANOVA) followed by post-hoc Dunnet, the homogeneity of the groups was confirmed by $\mathrm{CV}$ (coefficient of variation of Pearson). The statistical analysis was performed with GraphPad Prism 5 (San Diego, CA, USA) program. P values $<0.05$ were considered significant.

\section{Results and Discussion}

Formation of the primary vascular complex, or angiogenesis, is a process characterized by branching and remodeling of primary capillary network. In this system, larger vessels originate a branched of smaller vessels which results in a complex and important structure in different physiological conditions (BUSCHMANN, SCHAPER, 1999; RIBATTI, 2016). Endogenous excitatory and inhibitory mediators regulate the homeostasis of this process, which when unbalanced can cause pathological angiogenesis such as in tumor formation, or trigger a neoplasic tissue formation (MELO-REIS et al., 2010; RIBATTI, 2014).

Because angiogenic process is common during tumor growth (RIBATTI, 2014) and due to the carcinogenic potential of BF (VETTER, 2009; VIRGILIO et al., 2015), we expected AEB would be able to induce an increase in number of CAMs' vessels. However, as the number of vessels observed was similar between the control and treated groups (Figure 1) the AEB in different concentrations (0.1, $0.5,1,5,10 \mu \mathrm{g} / \mathrm{mL}$ ) failed to induce angiogenesis on CAM after exposition to extracts.

This fact above was confirmed when similar pattern of tissue vascularization between the control and exposed to the AEB was observed in membranes stained with $H \& E$ and analyzed microscopically (Figure 2).

Although an analysis of neovascularization showed that AEB did not promoted vascular changes, the membranes which received implants of this extract had exhibit opacity and tissue fibrosis (more pronounced in $10 \mu \mathrm{g} / \mathrm{mL}$ ) both signs of inflammation (Figure 3). These features has not observed in membranes exposed to saline gel (control). 
Figure 1. Microvascularization on CAM exposed to AEB. Graphic representation of AEB effect on microvessels of CAM, measured as VDI. Results described as the mean \pm standard error of the mean $(n=10)$, according analysis using one way ANOVA followed by Dunnet.

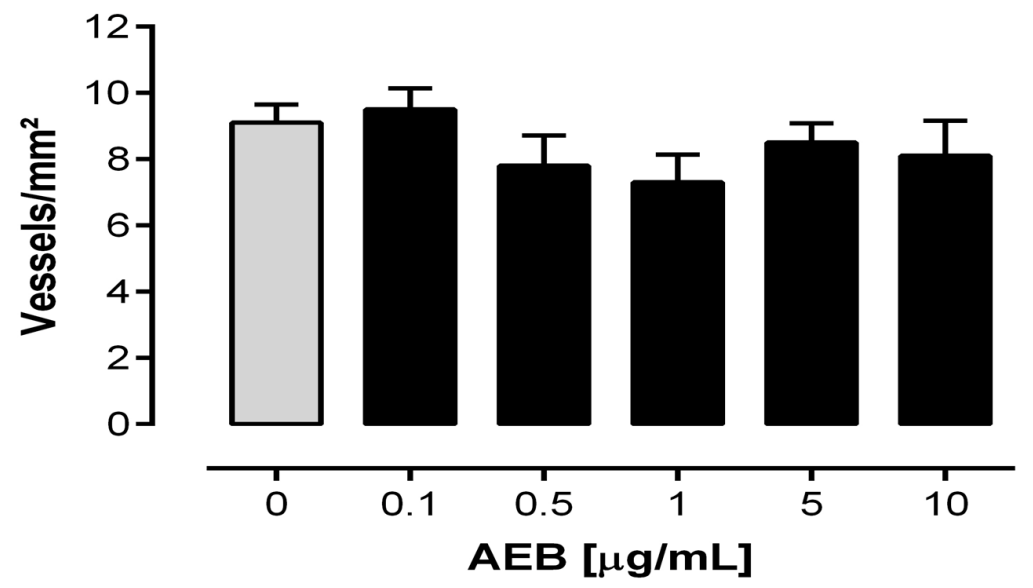

Figure 2. Representative photographs of microvascularization on CAM exposed to AEB. A) Histological sections of control; B) Histological sections of CAM exposed to $10 \mu \mathrm{g} / \mathrm{mL}$ AEB; D) The $\alpha$ symbol represents macrovessels and $\beta$ represents microvessels. Stained with H\&E, 40X.

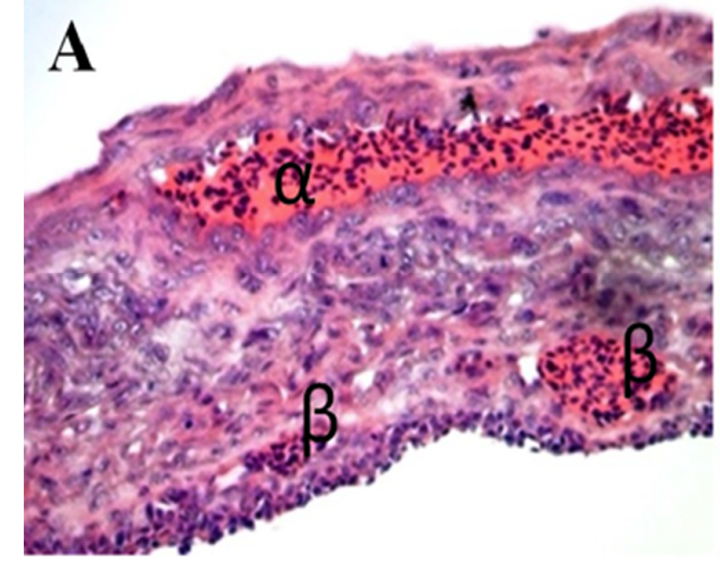

Figure 3B has shown an extensive fibrotic reaction called desmoplasia characterized by a strong accumulation of extracellular matrix (EGEBLAD et al., 2010; EIRO, VIZOSO, 2012). In addition, histological assessment of membranes stained with Masson's trichrome and Picro-sirius, showed an increase of collagen fibers (stained in blue) and presence of fibrilar collagen (red dots) in membranes treated with AEB (Figure 4).

It is well known that fibrosis is a common chronic inflammatory response occurring because tissue injury, as AEB caused in CAMs. Corroborating with

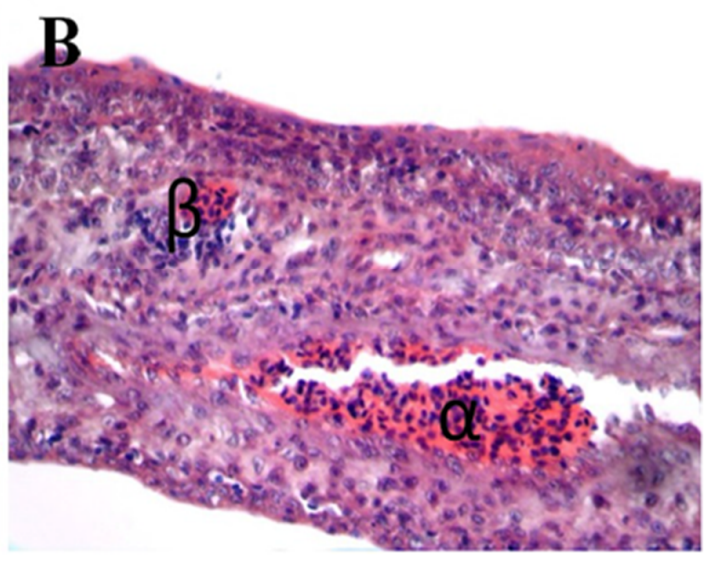

our study the literature described desmoplasia that on fibrosis formation there is excessive synthesis of extracellular matrix (including collagen and other proteins) (SEANDEL et al., 2001; CHUN et al., 2004), as well as histological changes such as increased number of inflammatory cells in the gastric mucosa of $\mathrm{C} 57 \mathrm{~B} / 6$ in mice that received aqueous extract of BF (COUSSENS, WERB, 2002; GOMES et al., 2012; LOTERSZTAJN, INSEL, 2013). As a result of this inflammatory process could trigger the formation of neoplastic tissue (COUSSENS, WERB, 2002; EIRO, VIZOSO, 2012). 
Figure 3. Representative photographs of fibrosis on CAM. A) Control membrane; B) Membrane exposed to $10 \mu \mathrm{g} /$ $\mathrm{mL}$ of $\mathrm{AEB}$. Arrow indicates fibrosis.

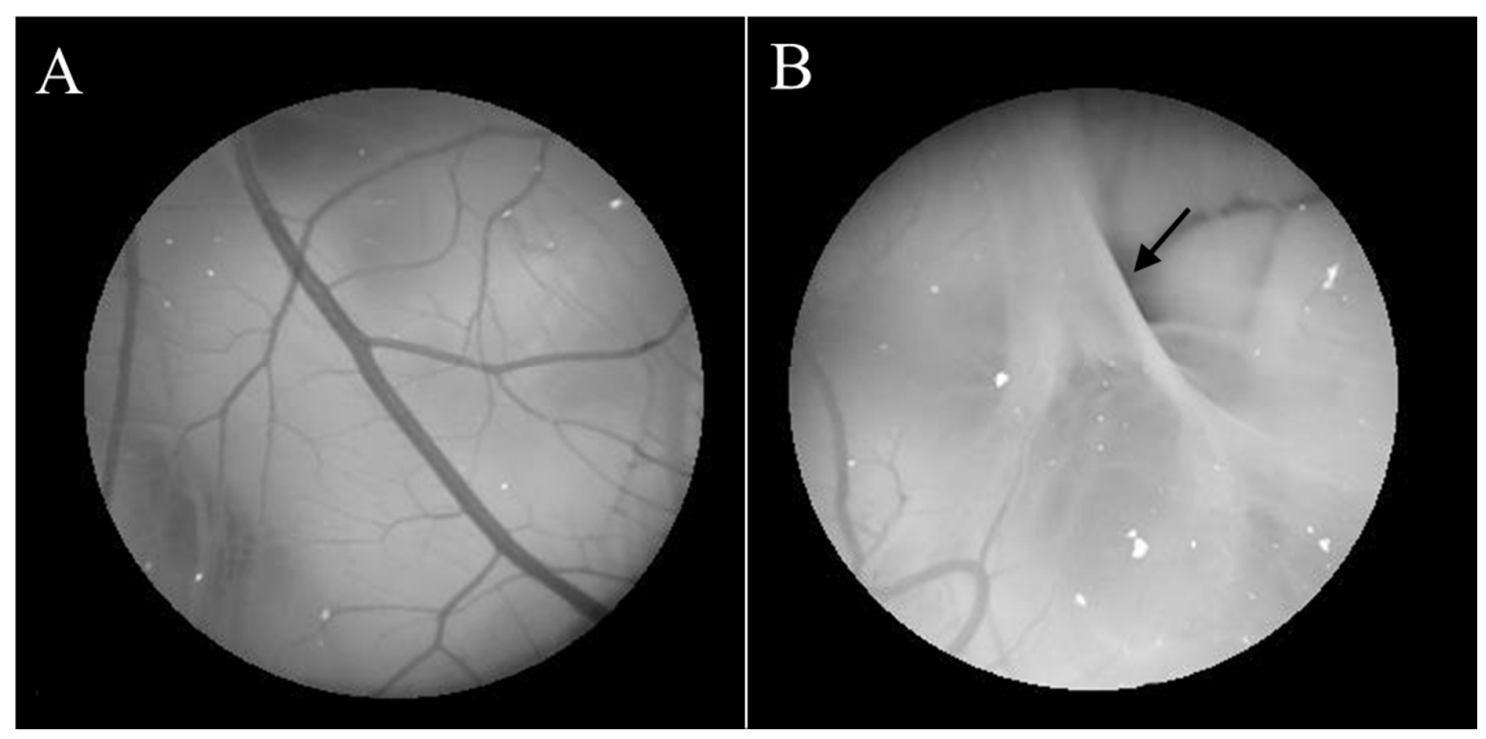

Figure 4. Representative histological sections. A and B represents respectively control membranes and membranes exposed to AEB $(10 \mu \mathrm{g} / \mathrm{mL})$, both stained with Masson's Trichrome, the dark blue color shows the increase of collagen fibers. C and D represents respectively control membranes and membranes exposed to AEB $(10 \mu \mathrm{g} / \mathrm{mL})$ stained with picro-sirius, the green dots represent reticular collagen and red points fibrilar collagen.

\section{A $\quad$ B}

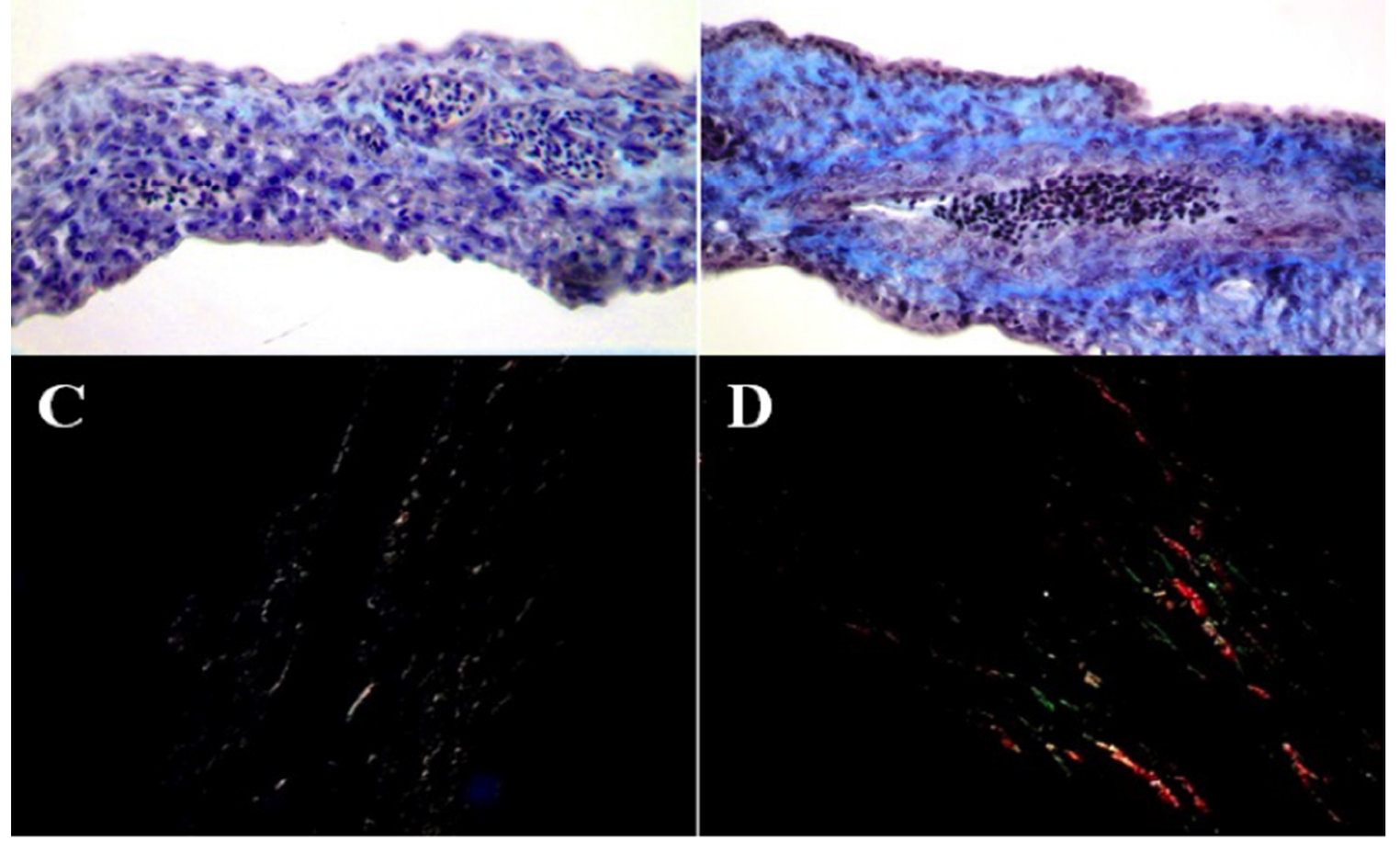


Besides the fibrosis observed on membranes, the embryos exposed to 5 or $10 \mu \mathrm{g} / \mathrm{mL}$ AEB, showed changes in the normal pattern like poor face formation and poor closing of abdominal wall (data not shown). Embryos exposed to concentrations of $0.1,0.5$ and $1 \mu \mathrm{g} / \mathrm{mL}$ AEB showed normal pattern of development as control animals. Furthermore, the highest concentration of AEB $(15 \mu \mathrm{g} / \mathrm{mL})$ was lethal to embryos. Supporting our data, previous studies showed maternal toxicity, embryotoxicity and abnormalities in offspring of rats that consumed BF (GERENUTTI et al., 1992). Similarly, Yasuda et al. (1974) observed embryos with multiple malformations, including abnormalities marks and incomplete fusion of the sternum after pregnant rat intake a diet with $30 \%$ of this plant.

To verify presence of toxic metabolites and correlate with deleterious effects on CAM, analyzes of chemical composition were performed using AEB. Previously, Gil da Costa et al. (2012), described that BF contains a large number of chemically heterogeneous compounds with many activities and often poorly understood. Our results revealed the presence of cyanogenic glycosides, volatile acids and tannins in the aqueous extract of bracken fern (Table 1). After hydrolyzed, cyanogenic glycosides release hydrocyanic acid (HCN) that might trigger poisoning in animals, which ingested the BF (ALONSO-AMELOT, AVENDANO, 2002). About tannins toxic effects, has been observed after ingestion, it is known that along with its metabolites (gallic acid and pyrogallol digallic acid) are responsible for the toxic effects observed, renal tubular necrosis, mainly, with interstitial edema and hemorrhage and gastrointestinal ulcers (SEBASTIAN et al., 2007).

Table 1. Presence/absence of chemical compounds on AEB.

\begin{tabular}{lc}
\hline Metabolite & Result \\
\hline Anthocyanin glycosides & absence \\
Saponin glycosides & absence \\
Cyanogenic glycosides & presence \\
Amino groups & absence \\
Fixed acids & absence \\
Volatile acids & presence \\
Tannins & presence \\
\hline
\end{tabular}

\section{Conclusion}

Although, significant effects on the CAM's vasculature has not observed, tissue aggression was detected. A desmoplasia (an extensive inflammatory signal triggered by tissue injury) was depicted from the experiment as increase of collagen fibers and presence of fibrilar collagen on membranes. Besides with changes caused on embryos as well as the presence of toxic substances in the AEB (cyanogenic glycosides, volatile acids and tannins) it can be possible to infer an important deleterious effect of this bracken fern extract on CAM and embryos studied.

\section{Acknowledgements}

The authors would like to thank DaGranja Agroindustrial Ltd. for providing the fertile chicken eggs. This study was supported by the Pontifícia Universidade Católica do Paraná/Programa Institucional de Bolsas de Iniciação Científica do Conselho Nacional de Pesquisa (PUCPR/CNPq). We would like to thank Dr. Indalécio Sutil and staff, MSc. Ana Paula Camargo Martins and staff, and Mr. Maurício José Barbosa, whose support was fundamental to complete this research. 


\section{Author contributions}

The authors made substantial contributions to the conception and design, acquisition, analysis and interpretation of data, drafting the article and revising it critically for important intellectual content.

\section{References}

ALONSO-AMELOT, M. E. The link between bracken fern and stomach cancer: Milk. Nutrition, New York, v. 13, n. 7-8, p. 694-696, 1997.

ALONSO-AMELOT, M. E.; AVENDANO, M. Human carcinogenesis and bracken fern: a review of the evidence. Current Medicinal Chemistry, Cambridge, v. 9, n. 6, p. 675-686, 2002.

BOLLER, C.; PRADO, M. R. M.; TOLEDO, M. G. T.; GARBELINI, M. C. L.; ORTOLANI-MACHADO, C. F.; NAKASHIMA, T.; ZIBETTI, R. G. M. The antiangiogenic effect of Chamomila recutita aqueous extract determined using a modified chicken chorioallantoic membrane ex ovo assay. International Journal of Current Microbiology and Applied App Sciences, Tamilnadu, v. 4, n. 8, p. 231-243, 2015.

BUSCHMANN, I.; SCHAPER, W. Arteriogenesis versus angiogenesis: two mechanisms of vessels growth. News in Phisiological Sciences, Maryland, v. 14, n. 3, p. 121125, 1999.

CHUN, T. H.; SABEH, F.; OTA, I.; MURPHY, H.; MCDONAGH, K. T.; HOLMBECK, K.; BIRKEDALHANSEN, H.; ALLEN, E. D.; WEISS, S. J. MT1-MMPdependent neovessel formation within the confines of the threedimensional extracellular matrix. The Journal of Cell Biology, New York, v. 167, n. 4, p. 757-767, 2004.

COUSSENS, L. M.; WERB, Z. Inflammation and cancer. Nature, New York, v. 420, n. 6917, p. 860-867, 2002.

EGEBLAD, M.; RASCH, M. G.; WEAVER, V. M. Dynamic interplay between the collagen scaffold and tumor evolution. Current Opinion in Cell Biology, Amsterdam, v. 22, n. 5, p. 697-706, 2010.

EIRO, N.; VIZOSO, F. J. Inflammation and cancer. World Journal of Gastrointestinal Surgery, California, v. 4, n. 3, p. 62-72, 2012.

EUN, J. P.; KOH, G. Y. Suppression of angiogenesis by the plant alkaloid, sanguinarine. Biochemical and Biophysical Research Communications, Amsterdam, v. 317, n. 2, p. 618-624, 2004.
FRANCO, J.; NAKASHIMA, T.; FRANCO, L.; BOLLER, C. Chemical composition and antimicrobial in vitro activity of the essential oil Eucalyptus cinerea F. Mull. ex Benth., Myrtaceae, extracted in different time intervals. Revista Brasileira de Farmacognosia, Curitiba, v. 15, n. 3, p. 191-194, 2005.

FREITAS, K.; GIMENEZ DE SOUZA, F.; WATHIER, J.; LEITOLIS, A.; PEREIRA, L. F. Preliminary analysis of chorioallantoic membrane of chick embryo (CAM) toxicity induced by lidocaine. Odonto, Porto Alegre, v. 21, n. 41-42, p. 39-45, 2013.

GERENUTTI, M.; SPINOSA, H. S.; BERNARDI, M. M. Effects of bracken fern (Pteridium aquilinum (L.) Kuhn) feeding during the development of female rats and their offspring. Veterinary and Human Toxicology, Kansas, v. 34, n. 4, p. 307-310, 1992.

GIL DA COSTA, R. M.; BASTOS, M. M. S. M.; OLIVEIRA, P. A.; LOPES, C. Bracken-associated human and health hazards: chemical, biological, and pathological evidence. Journal of Hazardous Materials, Amsterdam, v. 15, n. 203-204, p. 1-12, 2012.

GOMES, J.; MAGALHÃES, A.; MICHEL, V.; AMADO, I. F.; ARANHA, P.; OVESEN, R. G.; HANSEN, H. C. B.; GÄRTNER, F.; REIS, C. A.; TOUATI, E. Pteridium aquilinum and its ptaquiloside toxin induced DNA damage response in gastric epithelia cells, a link with gastric carcinogenesis. Toxicological Sciences, Oxford, v. 126, n. 1, p. 60-71, 2012.

HAZEL, S. J. A novel early chorioallantoic membrane assay demonstrates quantitative and qualitative changes caused by antiangiogenic substances. Journal of Laboratory and Clinical Medicine, Amsterdam, v. 141, n. 3, p. 217-228, 2003.

KLUEH, U.; DORSKY, D. I.; MOUSSY, F.; KREUTZER, D. L. Ex ova chick chorioallantoic membrane as a novel model for evaluation of tissue responses to biomaterials and implants. Journal of Biomedical Material Research, New York, v. 67, n. 3, p. 838-843, 2003.

LOTERSZTAJN, S.; INSEL, P. A. AJP-Cells begins a Theme series on tissue fibrosis. American Journal of Physiology - Cell Physiology, Maryland, v. 304, n. 3, p. C215, 2013.

MASUDA, E. K.; KOMMERS, G. D.; MARTINS, T. B.; BARROS, C. S. L.; PIAZER, J. V. M. Morphological factors as indicators of malignancy of squamous cell carcinomas in cattle exposed naturally to bracken fern (Pteridium aquilinum). Journal of Comparative Pathology, Amsterdam, v. 144, n. 1, p. 48-54, 2011. 
MELKONIAN, G.; MUNOZ, N.; CHUNG, J.; TONG, C.; MARR, R.; TALBOT, P. Capillary plexus development in the day Wve to day six chick chorioallantoic membrane is inhibited by cytochalasin D and suramin. Journal of Experimental Zoology, New Jersey, v. 292, n. 1, p. 241254, 2002.

MELO-REIS, P. R.; ANDRADE, L. S.; SILVA, C. B.; ARAÚJO, L. M. M.; PEREIRA, M. S.; MRUE, F.; CHEN-CHEN, L. Angiogenic activity of Synadenium umbellatum Pax latex. Brazilian Journal of Biology, São Paulo, v. 70, n. 1, p. 189-194, 2010.

MENG, H.; GUO, J.; SUN J. Y.; PEI, J. M.; WANG, Y. M.; ZHU, M. Z.; HUANG, C. Angiogenic effects of the extracts from Chinese herbs: Angelica and Chuanxiong. The American Journal of Chinese Medicine, New York, v. 36, n. 3, p. 541-554, 2008.

PANTER, K. E.; GARDNER, D. R.; LEE, S. T.; PFISTER, J. A.; RALPHS, M. H.; STEGELMEIER, B. L.; JAMES, L. F. Important poisonous plants of the United States. In: GUPTA, R. C. (Ed.). Veterinary toxicology: basic and clinical principles. New York: Academic Press, 2007. p. 825-872.

RIBATTI, D. The chick embryo chorioallantoic membrane as a model for tumor biology. Experimental Cell Research, New York, v. 328, n. 1, p. 314-324, 2014.

The chick embryo chorioallantoic membrane (CAM). A multifaceted experimental model. Mechanisms of Development, Stockholm, v. 141, p. 70-77, 2016.

ROOS, K.; RÖDEL, H. G.; BECK, E. Short- and longterm effects of weed control on pastures infested with Pteridium arachnoideum and an attempt to regenerate abandoned pastures in South Ecuador. Weed Research, Massachusetts, v. 5, n. 2, p. 165-176, 2010.

SEANDEL, M.; NOACK-KUNNMANN, K.; ZHU, D.; AIMES, R. T.; QUIGLEY, J. P. Growth factor-induced angiogenesis in vivo requires specific cleavage of fibrillar type I collagen. Blood, Washington, v. 97, n. 8, p. 23232332, 2001.

SEBASTIAN, M. N.; BASKIN, S. E.; CZERWINSKI, S. E. Renal toxicity. In: GUPTA, R. C. (Ed.). Veterinary toxicology: basic and clinical principles. New York: Academic Press, 2007. p. 161-176.

SHAHIN, M.; SMITH, B. L.; PRAKASH, A. S. Bracken carcinogens in the human diet. Mutation Research, California, v. 443, n. 1-2, p. 69-79, 1999.
SMITH, B. L.; SEAWRIGHT, A. A. Bracken fern (Pteridium spp.) carcinogenicity and human health $-\mathrm{a}$ brief review. Natural Toxins, Massachusetts, v. 3, n. 1-2, p. 1-5, 1995.

TOMAZELI, L.; LEITOLIS, A.; FREITAS, K.; SILVA, M. C.; REPEKE, C. E.; CAETANO JUNIOR, Z.; ELÍFIO-ESPOSITO, S. L.; TRINDADE GRÉGIO, A. M.; NORONHA, L.; PEREIRA, L. F. Evaluation of prilocaine-induced toxicity in mice tissues and chick embryo chorioallantoic membranes (CAM). Pharmacologyonline, Salerno, v. 1, p. 31-40, 2015.

VALDES, T. I.; KREUTZER, D.; MOUSSY, F. The chick chorioallantoic membrane as a novel in vivo model for the testing of biomaterials. Journal of Biomedical Material Research, New York, v. 62, n. 2, p. 273-282, 2002.

VETTER, J. Biological hazard our of age: bracken fern [Pteridium aquilinum (L.) Kuhn] - a review. Acta Veterinaria Hungarica, Budapest, v. 57, n. 1, p. 183-196, 2009.

Toxicological medicinal aspects of the most frequent fern species, Pteridium aquilinum (L.) Kuhn. In: KUMAR, A.; FERNANDEZ, H.; REVILLA, M. A. (Ed.). Working with ferns: issues and applications. New York: Springer, 2010. p. 361-375.

VIRGILIO, A.; SINISI, A.; RUSSO, V.; GERARDO, S.; SANTORO, A.; GALEONE, A.; TAGLIALATELASCAFATI, O.; ROPERTO, F. Ptaquiloside, the major carcinogen of bracken fern, in the pooled raw milk of healthy sheep and goats: an underestimated, global concern of food safety. Journal of Agricultural and Food Chemistry, Washington, v. 63, n. 19, p. 4886-4892, 2015.

YAMADA, K.; OJIKA, M.; KIGOSHI, H. Ptaquiloside, the major toxin of bracken, and related terpene glycosides: chemistry, biology and ecology. Natural Product Reports, San Diego, v. 24, n. 4, p. 798-813, 2007.

YANG, S. H.; LIN, J. K.; HUANG, C. J.; CHEN, W. S.; LI, S. Y.; CHIU, J. -H. Silibinin inhibits angiogenesis via Flt-1, but not KDR, receptor up-regulation1. Journal of Surgical Research, Houston, v. 128, n. 1, p. 140-146, 2005.

YASUDA, Y.; KIHARA, T.; NISHIMURA, $\mathrm{H}$. Embryotoxic effects of feeding bracken fern (Pteridium aquilinum) to pregnant mice. Toxicology and Applied Pharmacology, Pennsylvania, v. 28, n. 2, p. 264-268, 1974. 
